\title{
Influences of some ecological factors on bacterial cellulose (BC) membrane forming process in Spirulina medium
}

\author{
Anh hương của một số yếu tố sinh thái tới quá trình tạo màng bacterial cellu- \\ lose $(B C)$ trên môi trường tảo xoắn Spirulina \\ Research article
}

Dinh Thi Kim Nhung*; Nguyen Thi Kim Ngoan

Hanoi Pedagogical University $N^{\circ}$ 2, Nguyen Van Linh Street, Xuan Hoa Ward, Phuc Yen Town, Vinh Phuc, Vietnam.

\begin{abstract}
Formed by a kind of bacteria called Gluconacetobacter, bacterial cellulose (biocellulose, BC) membrane, compared to cellulose from plants, has superior properties for the strength, toughness, durability and elasticity. The subjects of this study are bacteria being able to produce Bacterial cellulose in Spirulina medium. The study aims to investigate the influences of some ecological factors on the Bacterial cellulose membrane forming process in Spirulina medium, and then find out appropriate nutritional media and conditions for the fermentation in Bacterial cellulose forming process. The study has some major findings: (1) Select two strains of bacteria: Gluconacetobacter xylinus $\mathrm{T}_{6}$ and Gluconacetobacter xylinus $\mathrm{T}_{9}$, which prove to be capable of producing cellulose membrane to be used in making nourishing face masks for its thinness, smoothness, toughness and uniformity; (2) Find out the appropriate medium for the formation of Bacterial cellulose membrane, including $\left(\mathrm{NH}_{4}\right)_{2} \mathrm{SO}_{4}: 0,5(\mathrm{~g}), \mathrm{KH}_{2} \mathrm{PO}_{4}: 1(\mathrm{~g})$, glucose: $10(\mathrm{~g})$, algae powder: $20(\mathrm{~g})$, and distilled water: 1000 $(\mathrm{ml})$. Successful fermentation for membrane production could be done in appropriate $\mathrm{pH}$ of 5 and appropriate temperature of $32^{\circ} \mathrm{C}$. The ratio of surface area per volume of fermentation $(\mathrm{S} / \mathrm{V})$ is 0.8 , and the membrane can be collected after 5 days.
\end{abstract}

Màng cellulose vi khuẩn (Bacterial cellulose; Biocellulose; BC) do vi khuẩn Gluconacetobacter tạo ra có nhũng đặc tính vuoọt trội so với cellulose của thưc vật về độ dẻo dai, độ bền, chắc khỏe và độ đàn hồi. Đối tuợng: vi khuẩn có khả năng tạo màng Bacterial cellulose tù môi trường tảo xoắn Spirulina. Mục tiêu: Khảo sát ảnh hưởng của một số yểu tố đến quá trình tạo màng Bacterial cellulose trên môi truònng tảo xoắn Spirulina, tù đó tìm ra được môi truờng dinh duỡng và điều kiện thích hợp cho quá trình lên men tạo màng Bacterial cellulose. Kết quả: tuyển chọn được 2 chủng vi khuẩn Gluconacetobacter xylinus $T_{6}$ và Gluconacetobacter xylinus $T_{9}$ có khả năng tạo màng cellulose có đặc tính mỏng, nhã̃n, đồng đều, dai phù hợp với các tiêu chí làm mặt na dương da. Xác định được môi trưòng thich hợp cho sư hình thành màng Bacterial cellulose gồm (NH4) $\mathrm{SO}_{4}:$ 0,5 (g), $\mathrm{KH}_{2} \mathrm{PO}_{4}: 1$ (g), glucose: 10 (g), bột tảo: 20 (g), nuớc cất 1000 (ml) vói thòi gian thu màng là 5 ngày, pH thich hơp là 5 và nhiệt độ thuận lợi cho quá trình lên men tạo màng là $32^{\circ} \mathrm{C}$, tỉ lệ diện tích bề măt trên thể tích lên men là $S / V=0,8$.

Keywords: Gluconacetobacter, Bacterial cellulose, Spirulina

\section{Introduction}

Bacterial cellulose (or Biocellulose; BC) membrane formed by the bacterium Gluconacetobacter, has greatly similar structures and characteristics to cellulose in plants as they both consist of glucose molecules linked together by a $\beta$ 1,4glucosidic bond [5]. Unlike plant cellulose, Bacterial cellulose does not contain such compounds as ligin, pectin, hem- icellulose and wax, etc. As a result, Bacterial cellulose membrane has superior properties forits toughness, durability and elasticity. Thanks to its unique elasticity, Bacterial cellulose membrane is thought to be a new soursce of polymer and a solution to the search for new materials these days.

Raw materials used to cultivate Gluconacetobacter are available and diverse: old coconut water, molasses, cane water and rice water, for example. In this study, we choose 
to use Spirulina. If used frequently, Spriulina can help improve mental strength, fitness and beauty for users of different ages and genders. Thus, there is little doubt that Spirulina is an ideal medium for the culture of bacteria Gluconacetobacter. From these reasons mentioned above, we decided to do a research on the influences of some ecological factors on the Bacterial cellulose (BC) membrane forming process in Spirulina medium in order to find out appropriate and favourable media and conditions for the culture of selected bacteria Gluconacetobacter. In combination with the study on harvested membrane treatment process, this study largely contributes to the production of $100 \%$ - natural nourishing face masks for users.

\section{Materials and research methods}

\subsection{Stocks}

The bacteria seperated from vinegar-fermented membrane samples in Spirulina medium.

\subsection{Bacterial culture media}

Medium for bacteria isolation (MT1) is composed of Glucose: $20 \mathrm{~g},\left(\mathrm{NH}_{4}\right)_{2} \mathrm{SO}_{4}: 3 \mathrm{~g}, \mathrm{MgSO}_{4} \cdot 7 \mathrm{H}_{2} \mathrm{O}: 2 \mathrm{~g}$, agar - agar: $20 \mathrm{~g}$, peptone: $5 \mathrm{~g}, \mathrm{KH}_{2} \mathrm{PO}_{4}: 2 \mathrm{~g}, \mathrm{CaCO}_{3}: 10 \mathrm{~g}$, acetic $2 \%$, distilled water: $1000 \mathrm{ml}, \mathrm{pH} 5.5$.

Medium for membrane-forming fermetation (MT2) is composed of Glucose: $10 \mathrm{~g}, \quad\left(\mathrm{NH}_{4}\right)_{2} \mathrm{SO}_{4}: 0,5 \mathrm{~g}$, $\mathrm{MgSO}_{4} \cdot 7 \mathrm{H}_{2} \mathrm{O}: 1 \mathrm{~g}, \mathrm{KH}_{2} \mathrm{PO}_{4}: 1 \mathrm{~g}$, acetic $2 \%$, Spirulina powder: $20 \mathrm{~g}$, distilled water: $1000 \mathrm{ml}$.

\subsection{Methods}

\section{Microbiological methods:}

Isolating and selecting bacteria strains that are capable of forming Bacterial cellulose membrane: Isolating bacteria by critical dilution method [4].

Dying, observing cells in electronic microscopes: Get colonies in the tilt jelly tube, make smeared on a slide, fixed the smeared by heating a flame, staine cells by Gram stain method. Put on the template with objective 10-40 to observer then move the template under 100 oil objective with a magnification of 1000 times. If bacterial cells change to pink, they will be Gram-negative bacteria. If bacterial cells change to purple, they will be Gram-positive bacteria.

\section{Biochemical methods:}

Examining catalase activity: Drop a $\mathrm{H}_{2} \mathrm{O}_{2} 3 \%$ onto the surface of colonies. In the presence of bubbling, bacterial strains will have catalase activity (catalase + ). If not, they haven't catalase activity (catalase -).

Examing the aibility of ethanol oxidation into axetic: Culture bacterial strains which selected on the medium, inclu$\operatorname{ding}(\mathrm{g} / \mathrm{l})$ : yeast extract: $10 \mathrm{~g}$, ethanol: $10 \%-15 \%$ (vol $/ \mathrm{vol}$ ), water: $1000 \mathrm{ml}, \mathrm{pH} 6.8$ to 7.0 , Blue bromophenol (BPB) $0.04 \% 20 \mathrm{ml}$. In the presence of acetic acid, the medium will change from blue to yellow.

Identifying the ability of acetic acid oxidation: Culture bacterial strains which selected on the medium, including (g/l): yeast extract: $10 \mathrm{~g}$, Calcium acetate: $10 \mathrm{~g}$, agar: $20 \mathrm{~g}$, water: $1000 \mathrm{ml}, \mathrm{pH} 7.0$ to 7.2. In the presence of milk while ring, reaction will be positive. If not, reaction will be negative. Examing the ability to metabolize glycerol into dihydroxyaceton: Culture bacterial strains which selected on the medium, including (g/l): yeast extract: $0.3 \%$, corn extract: $3 \%$, Glycerol: $4 \%$; $\mathrm{CaCO}_{3}: 0.3 \%,\left(\mathrm{NH}_{4}\right)_{2} \mathrm{SO}_{4}: 0.1$ $\%$, water: $1000 \mathrm{ml}, \mathrm{pH}$ : 5.3. Drop Fehling's solution to test the dihydroxyaceton formation (with the appearance of precipitate $\mathrm{Cu}_{2} \mathrm{O}$ - red brick).

\section{Findings and discussion}

\subsection{Isolating and selecting possible microor- ganisms for the production of Bacterial cellu- lose membranes in Spirulina medium}

We isolated bacteria in a particular medium with raw Spirulina. 15 pure bacterial strains were collected. Having dyed Gram of these collected bacterial strains, they were all found to catch pink dye. Hence, it can be said that all selected bacterial samples are Gram-negative. Furthermore, check the biochemical characteristics of the bacterium Gluconacetobacter, result as follows:

\section{Table 1. The biochemical characteristics of the bacterium Gluconacetobacter}

\begin{tabular}{|c|c|c|c|}
\hline Ordinal & Characteristics & Phenomenon & Result \\
\hline 1 & Oxidation of ethanol into axetic & $\begin{array}{l}\text { Medium with Bromphenol Blue } 0.04 \% \text { change } \\
\text { from blue to yellow }\end{array}$ & + \\
\hline 2 & Catalase activity & The presence of bubbling & + \\
\hline 3 & Growth on Hoyer medium & Undeveloping biomass & \\
\hline 4 & $\begin{array}{l}\text { Metabolize glycerol into } \\
\text { dihydroxyaceton }\end{array}$ & $\begin{array}{l}\text { Appearance of precipitate } \mathrm{Cu}_{2} \mathrm{O} \text { - red brick after } \\
\text { fermentation }\end{array}$ & + \\
\hline 5 & Metabolize glucose into acid & $\begin{array}{l}\text { Halo appears around the colonies on medium con- } \\
\text { taining } \mathrm{CaCO}_{3}\end{array}$ & + \\
\hline 6 & The ability born brown pigment & No brown pigmentation & - \\
\hline 7 & The ability to synthesize cellulose & The scum of bacteria appear blue & $\overline{+}$ \\
\hline
\end{tabular}


Thus, six samples of bacteria called $\mathrm{T}_{4}, \mathrm{~T}_{6}, \mathrm{~T}_{8}, \mathrm{~T}_{8}, \mathrm{~T}_{10}, \mathrm{~T}_{12}$ were premilinarily selected. They belong to Gluconacetobacter xylinus species, Acetobacteriaceae family, Gluconacetobacter genus.

Six selected strains of bacteria are then cultured in humoral environment at the temperature of $30^{\circ} \mathrm{C}$ to observe the formation of Bacterial cellulose membrane. The results revealed that 2 strains of Gluconacetobacter bacteria prove able to produce cellulose membrane characterized by its thinness, smoothness, toughness and unifomity, matching the criteria of nourishing face masks production. Having compared these two bacterial strains, we found that the bacteria $\mathrm{T}_{9}$ can produce thinner, smoother and stronger membrane in an earlier time, so we decided to choose the bacteria $T_{9}$ as the subject of further study.

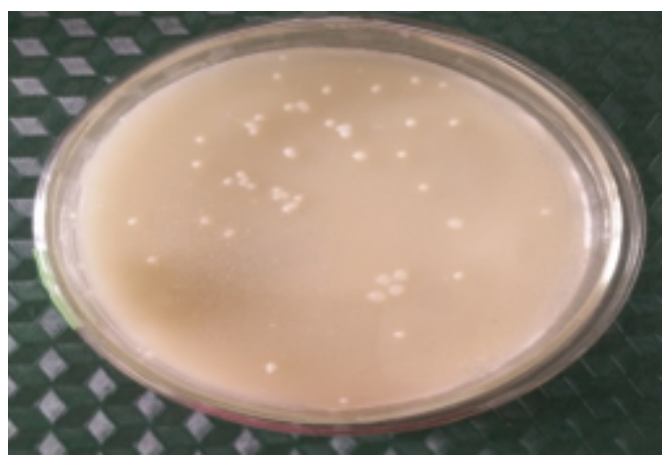

Figure 1. Colonies of isolated bacteria

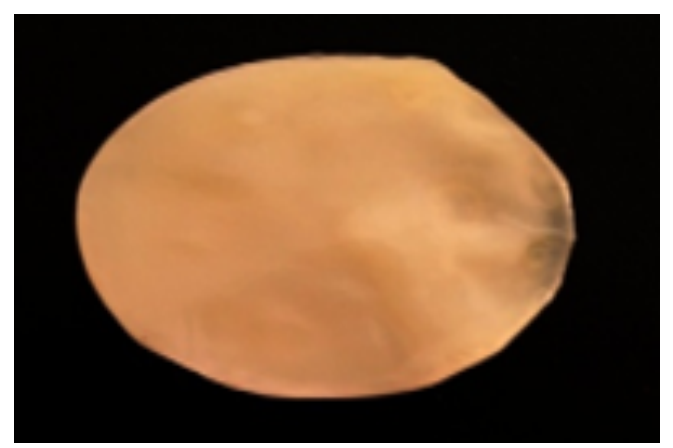

Figure 2. BC membrane produced from bacteria $\mathrm{T9}$

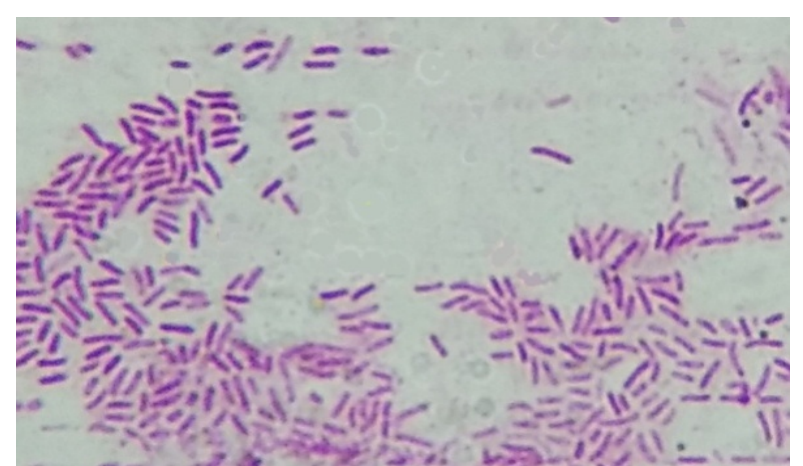

Figure 3. Cytological morphology of bacteria $T_{6}$ (x 1000)

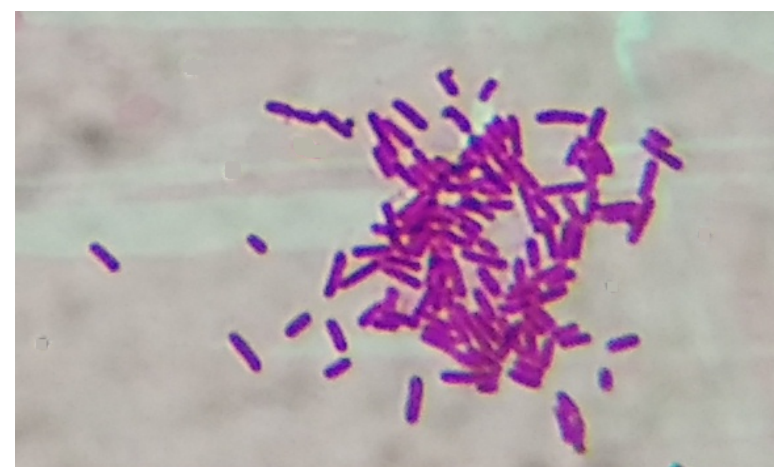

Figure 4. Cytological morphology of bacteria $\mathbf{T}_{9}$ (X 1000)

Bacteria $T_{9}$ are bacilli (rod-shaped bacteria), being individual or arranged in sequence. They are also characterized by their immobility, catalase activity and the oxidation of etylic alcohol into axetic acid. They can metabolize glycerol into dihydroxyaceton or glucose into gluconic acid. They do not grow in Hoyer medium [3].

We selected 2 out of 15 strains of Gluconacetobacter bacteria that could produce Bacterial cellulose mambrane use in nourishing face masks production for its thinness, smoothness, toughness and uniformity.

\subsection{Determing the appropriate concentration of Spirulina for the formation of Bacterial cel- lulose membrane}

In order to determine the appropriate amount of Spirulina for the Bacterial cellulose membrane formation, we changed the concentration of Spirulina from 0.1 to 30 grams per litre. Results are shown in the following chart:

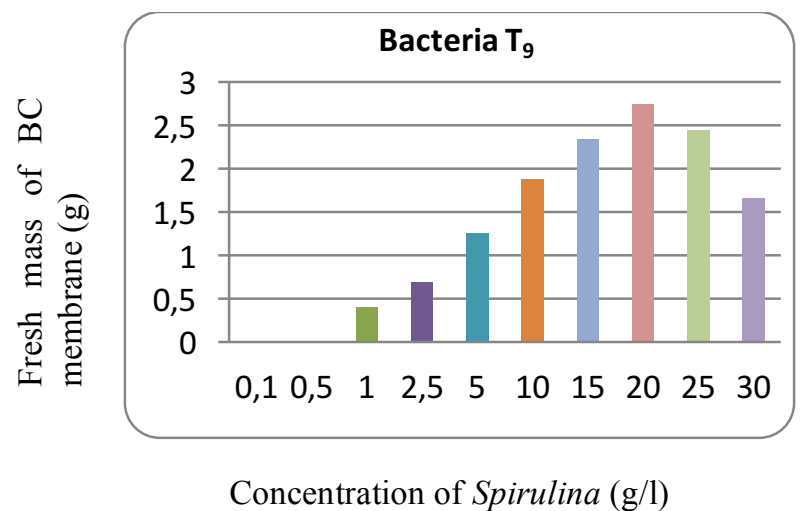

Figure 5. Influence of spirulina concentration on fresh mass of $\mathrm{BC}$ membrane

As can be seen from the chart, the thickest Bacterial cellulose membrane is produced at the Spirulina concentration of $20 \mathrm{~g} / \mathrm{l}$. With less than $15 \mathrm{~g} / 1$ Spirulina, the fresh weight of Bacterial cellulose membrane is smaller due to the lack of nutrients for the growth of bacteria. However, the growth of bacteria is also restricted if the concentration of nutrients is more than $20 \mathrm{~g} / \mathrm{l}$.

Thus, it can be concluded that $20 \mathrm{~g} / 1$ is the most suitable Spirulina concentration for the Bacterial cellulose membrane formation. 


\subsection{Influence of carbon on the formation of Bacterial cellulose membrane}

In order to studythe influence of carbon on Bacterial cellulose membrane formation, we first used glucose, saccharose, ethanol as the main sources of carbon. After 4 days, Bacterial cellulose membranes were collected to examine the influence of carbon sources on their formation. We found that glucose helps produce the membrane with the highest weight, so we decided to choose glucose as the carbon source of research. The amount of glucose varies from 0 to $20 \mathrm{~g} / 1$, and the findings are shown in the chart below:

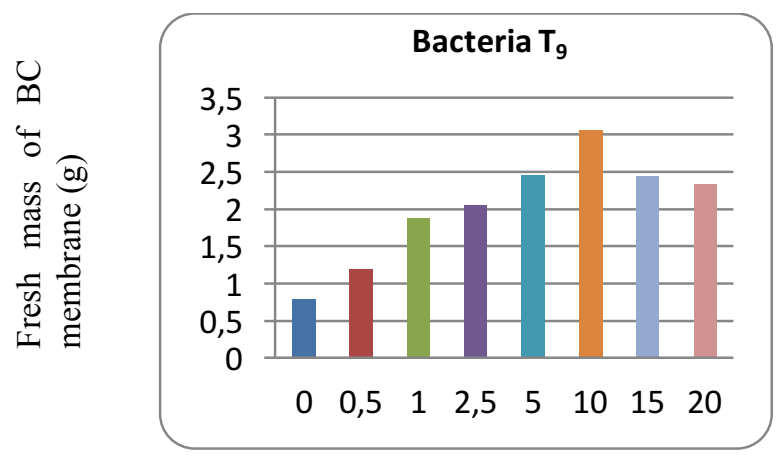

Concentration of glucose $(\mathrm{g} / \mathrm{l})$

Figure 6. Influence of glucose concentration on fresh mass of $\mathrm{BC}$ membrane

As illustrated from the chart, the thickest Bacterial cellulose membrane is produced at the glucose concentration of $10 \mathrm{~g} / 1$. With less than $5 \mathrm{~g} / \mathrm{l}$, less glucose is produced due to the insufficient amount of cutured humour for the growth of bacteria. As a result, the Bacterial cellulose membrane weighs less. In contrast, when the concentration of glucose is more than $15 \mathrm{~g} / 1$, it cannot be used up by bacteria. Excess glucose converts into gluconic acid, reducing $\mathrm{pH}$ and thus inhibiting the synthesis of glucose.

To sum up, $10 \mathrm{~g} / 1$ is the most appropriate amount of glucose for the Bacterial cellulose membrane formation.

\subsection{Examing the influence of $\left(\mathrm{NH}_{4}\right)_{2} \mathrm{SO}_{4}$}

$\mathrm{NH}_{3}$ and $\mathrm{NH}_{4}^{+}$are considered the most easily-absobed source of nitrogen for microorganisms. Hence, $\left(\mathrm{NH}_{4}\right)_{2} \mathrm{SO}_{4}$ is selected as the nitrogen source of research. The concentration of $\left(\mathrm{NH}_{4}\right)_{2} \mathrm{SO}_{4}$ varies from 0 to $3 \mathrm{~g} / \mathrm{l}$, and the findings are illustrated in the chart below:

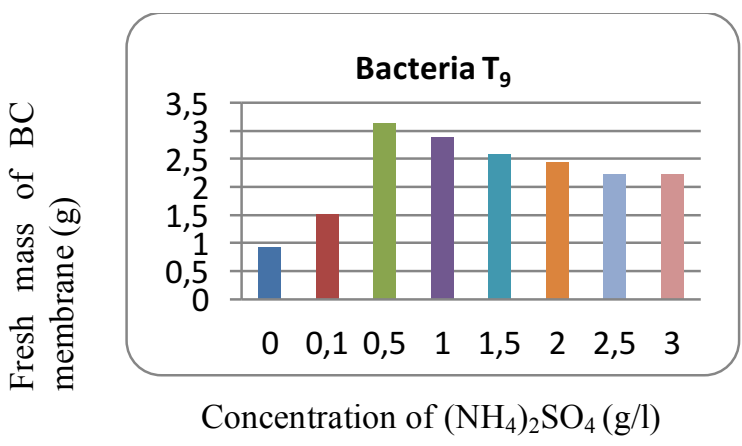

Figure 7. Influence of $\left(\mathrm{NH}_{4}\right)_{2} \mathrm{SO}_{4}$ concentration on the fresh mass of $\mathrm{BC}$ membrane
As can be seen from the chart, with the $\left(\mathrm{NH}_{4}\right)_{2} \mathrm{SO}_{4}$ concentration of $0.5 \mathrm{~g} / 1$, the thickest Bacterial cellulose membrane is produced. At the amount of more than $1 \mathrm{~g} / 1$, the fresh mass of Bacterial cellulose membrane is small. It can be explained by the fact that when the bacteria do not use up the nitrogen, excess nitrogen inhibits the growth of bacteria.

Hence, $0.5 \mathrm{~g} / 1$ is the most appropriate concentration of $\left(\mathrm{NH}_{4}\right)_{2} \mathrm{SO}_{4}$ for Bacterial cellulose membrane formation.

\subsection{Examining the influence of $\mathrm{KH}_{2} \mathrm{PO}_{4}$}

The presence of phosphorus compounds and its concentration in the solution has a strong influence on the metabolism of microorganisms. This leads to our decision of studying the influence of $\mathrm{KH}_{2} \mathrm{PO}_{4}$ on the formation of Bacterial cellulose membrane by bacteria $\mathrm{T}_{9}$. The concentration of $\mathrm{KH}_{2} \mathrm{PO}_{4}$ varies from 0 to $3 \mathrm{~g} / \mathrm{l}$. The resuts are shown in the following chart:

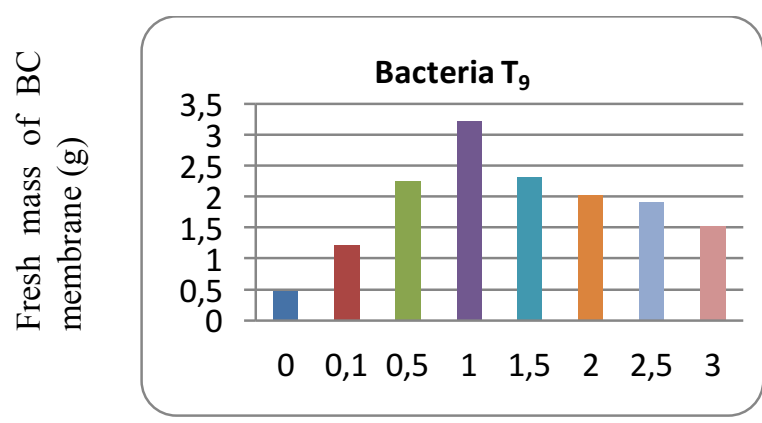

Concentration of $\mathrm{KH}_{2} \mathrm{PO}_{4}(\mathrm{~g} / \mathrm{l})$

Figure 8. Influence of $\mathrm{KH}_{2} \mathrm{PO}_{4}$ on the fresh mass of $\mathrm{BC}$ membrane

As illustrated in the chart, bacterium $\mathrm{T}_{9}$ produces the thickest Bacterial cellulose membrane at the $\mathrm{KH}_{2} \mathrm{PO}_{4}$ concentration of $1 \mathrm{~g} / \mathrm{l}$. When $\mathrm{KH}_{2} \mathrm{PO}_{4}$ concentration is less than 0.5 $\mathrm{g} / \mathrm{l}$, the fresh mass of Bacterial cellulose membrane is small as too low concentration of phosphorus and potassium affects their participation in the formation of coenzyme catalysts for reactions in the growth process. On the other hand, more than $1.5 \mathrm{~g} / 1 \mathrm{KH}_{2} \mathrm{PO}_{4}$ leads to the excess of phosphorus and potassium, changing the physical and chemical characteristics of the environment and inhibiting the growth of bacteria.

To conclude, $1 \mathrm{~g} / 1$ is the most appropriate concentration of $\mathrm{KH}_{2} \mathrm{PO}_{4}$ for the formation of Bacterial cellulose membrane.

\subsection{Influence of culture time on the formation of Bacterial cellulose membrane}

When culturing Gluconacetobacter xylinus $\mathrm{T}_{9}$ in the medium MT2 at the temperature of $30^{\circ} \mathrm{C}$, we found out that: On the first day, due to the movement from breeding environment into the fermentation one, there is a sudden change in environmental conditions. As a result, the number of cells is not large enough to produce cellulose. After 2 days, secondary threads appear in succession in aligned holes on the surface of bacterial cells. Then they twist together to form microfibers settling to the bottom. Next, cellulose 
strips overlap and twist together to form thin white sheet of cellulose on the surface. On the third day, a very thin cellulose membrane appears on the surface of fermentation vessel. The amount of cellulose booms from the fouth day to the sixth day of culture process. This is the time for the maximum cellulose biosynthesis of bacteria thanks to environment adaptation and sufficent cells.

Table 2. Influence of culture time on the formation of BC membrance from bacteria G. xylinus $\mathbf{T}_{9}$

\begin{tabular}{cclcc} 
Ordinal & Days & Properties of Bacterial cellulose membrane & $\mathrm{M} \pm \mathrm{m}$ & $\delta(\%)$ \\
\hline 1 & 3 & Very thin, transparent and smooth & $1.17 \pm 0.02$ & 0.03 \\
2 & 4 & Thin, transparent and smooth & $1.25 \pm 0.01$ & 0.02 \\
$\mathbf{3}$ & $\mathbf{5}$ & Thin, transparent, tough and smooth & $\mathbf{2 . 4 5} \pm \mathbf{0 . 0 2}$ & $\mathbf{0 . 0 3}$ \\
4 & 6 & Holes on the surface & $3.05 \pm 0.01$ & 0.02 \\
5 & 7 & Suspended in the solution & $3.65 \pm 0.02$ & 0.03 \\
6 & 8 & Near the bottom of fermentation vessel & $4.05 \pm 0.01$ & 0.02
\end{tabular}

M: Average mass of the membrane

$m$ : Mean error

$\delta:$ Average squared deviation

As can be seen in Table 2, the fresh mass of Gluconacetobacter xylinus $\mathrm{T}_{9}$ membrane increases with time of culture. The longer culture time is, the greater Bacterial cellulose membrane is. The volume of membrane increases sharply from Day 4 to Day 6, from $1.25 \pm 0.01(\mathrm{~g})$ to $3.05 \pm 0.01(\mathrm{~g})$ On the $6^{\text {th }}$ day, the growth of membrane decreases constantly. The difference between Day 6 and Day 7 is about $0.60(\mathrm{~g})$ compared to $1.20(\mathrm{~g})$ between Day 4 and Day 5. There is a slight increase between Day 7 and Day 8. As the research aims at thin and tough Bacterial cellulose membrane production, we choose to collect the membrane on Day 5.

To conclude, thin and tough Bacterial cellulose membrane is best produced by culturing Gluconacetobacter xylinus $T_{9}$ in the time length of 5 days.

\subsection{Influence of $\mathrm{pH}$ on the formation of Bac- terial cellulose membrane}

$\mathrm{pH}$ is measured by the concentration of ions $\mathrm{H}^{+}$and $\mathrm{OH}^{-}$ in the solution. $\mathrm{pH}$ of the solutionhas direct and indirect influence on the cells' physiological properties, it also affects the possibility of forming Bacterial cellulose membrane of bacteria Gluconacetobacter xylinus $\mathrm{T}_{9}$ [2].

To find down the appropriate $\mathrm{pH}$ for the growth of cells in Bacterial cellulose membrane, we culture the bacteria in some media with different $\mathrm{pH}$ values at the same temperature of $30^{\circ} \mathrm{C}$ in 5 days. The results are illustrated as follows:

Table 3. Influence of $\mathrm{pH}$ on the formation of $\mathrm{BC}$ membrane from bacteria G. xylinus $\mathrm{T}_{9}$

\begin{tabular}{cclrc} 
Ordinal & $\mathrm{pH}$ & \multicolumn{1}{c}{ Propeties of Bacterial cellulose membrane } & $\mathrm{M} \pm \mathrm{m}$ & $\delta(\%)$ \\
\hline 1 & 3 & Thin, transparent, smooth & $1.27 \pm 0.02$ & 0.03 \\
2 & 4 & Thin, tough, smooth & $2.59 \pm 0.01$ & 0.02 \\
$\mathbf{3}$ & $\mathbf{5}$ & Thin, transparent, tough, smooth & $\mathbf{3 . 1 5} \pm \mathbf{0 . 0 2}$ & $\mathbf{0 . 0 3}$ \\
4 & 6 & Thin, tough, viscous & $2.62 \pm 0.01$ & 0.02 \\
5 & 7 & No formation & & \\
6 & 8 & No formation & &
\end{tabular}

M: average mass of membrane

$m$ : Mean error

$\delta:$ average squared deviations

Table 3 shows that different amounts of cellulose are collected with the use of different $\mathrm{pH}$ values of solution. Along with cellulose synthesis of Gluconacetobacter bacteria is its cellulase synthesis. The more cellulase is produced, the less possibility of polimerization bacteria haveto produce cellulose. Thus, less cellulose is produced. With high $\mathrm{pH}(\mathrm{pH}>5)$, more cellulase is produced than cellulose, and vice verse, cellulose production increases if $\mathrm{pH}$ is less than 5. In addition, cellulose synthesis and glucose oxidation give more ions for the metabolism, which reduces the amount of glucose used for the cellulose formation. The appearance of byproducts when glucose is oxidised by some enzymes could be used to explain why different species of microorganisms perform different cellulose biosynthesis at different $\mathrm{pH}$ values and with different sources of carbon [1]. Gluconacetobacter xylinus $\mathrm{T}_{9}$ bacteria are cultured in Spirulina medium in 5 days at $\mathrm{pH} 7$. At $\mathrm{pH} 8$, there is no Bacterial cellulose membrane formation. From $\mathrm{pH} 4$ to $\mathrm{pH} 6$, membranes with the similar thickness are formed. At $\mathrm{pH} 5$, the mass of cellulose reaches the highest; tough and smooth Bacterial cellulose membranes appear. These results are in light of those in the study by Hestrin and 
Schramm (1954) [6]. pH 5 is determined the optimum to minimize the change of ion concentration in culture environment, so it is selected to culture bacteria $T_{9}$.

In conclusion, $\mathrm{pH} 5$ is the most appropriate for the fermentation in Bacterial cellulose membrane formation of bacterium $\mathrm{G}$. xylinus $\mathrm{T}_{9}$.

\subsection{Influence of temperature on the formation of Bacterial cellulose membrane}

Not only does temperature affect the growth but it also playsadecisive role in the formation of Bacterial cellulose of bacteria $G$. xylinus $T_{9}$. When being cultured, bacteria grow slowly at low temperatures, so the time of culture is longer. This reduces the possibility of cellulose synthesis. High temperatures can lead to strong respiration, negatively affecting cellulose synthesis [7]. In order to determine the best temperature for fermentation, bacteria G. xylinus $\mathrm{T}_{9}$ are cultured in warm Binder container (Germany) at $\mathrm{pH}$ : 5 , but at different temperatures. After 5 days, Bacterial cellulose membranes are collected to determine their fresh weight. Results are shown in the following table:

Table 4. Influence of temperature on the BC membrane formation from bacterium G. xylinus $\mathbf{T}_{9}$

\begin{tabular}{ccccc} 
Ordinal & $\begin{array}{c}\text { Temperature } \\
\left({ }^{0} \mathrm{C}\right)\end{array}$ & Prperties of Bacterial cellulose membrane & $\mathrm{M} \pm \mathrm{m}$ & $\delta(\%)$ \\
\hline 1 & 15 & No formation & & \\
2 & 20 & Thin cellulose thread ssuspended in the solution & & $\mathbf{0 . 0 2}$ \\
$\mathbf{3}$ & $\mathbf{2 5}$ & Thin, transparent, tough, smooth & $\mathbf{2 . 8 5} \pm \mathbf{0 . 0 1}$ & $\mathbf{3 . 0 0} \pm \mathbf{0 . 0 1}$ \\
4 & 28 & Thin, tough, smooth & $\mathbf{3 . 2 5} \pm \mathbf{0 . 0 2}$ & $\mathbf{0 . 0 3}$ \\
5 & 30 & Thin, tough, smooth & $\mathbf{3 . 3 4} \pm \mathbf{0 . 0 2}$ & $\mathbf{0 . 0 3}$ \\
6 & 32 & Thin, tough, smooth & $\mathbf{3 . 1 2} \pm \mathbf{0 . 0 1}$ & $\mathbf{0 . 0 2}$ \\
7 & 35 & Thin, tough, smooth & &
\end{tabular}

M: average mass of membrane

$m$ : Mean error

$\delta$ : average squared deviation

As can be seen from Table 4, temperature has a great effect on bacteria $G$. xylinus $\mathrm{T}_{9}$ like other species. A factor that decides the growth of bacteria is the susceptibility to temperature in reactions catalyzed by enzymes. At low temperatures $\left(15^{\circ} \mathrm{C}-20^{\circ} \mathrm{C}\right)$, enzyme-catalyzed reactions occur slowly, restricting the growth of bacteria. This only produces cellulose threads suspended in the solution and no formation of membrane appears. Like other chemical reactions, the rate of enzyme-catalyze dreactions increases when the temperature increases. This is followed by the increase of metabolism and quick growth of bacteria. Thus, more cellulose is produced $\left(25^{\circ} \mathrm{C}: 2,85 \pm 0,01 \mathrm{~g} ; 30^{\circ} \mathrm{C}: 3,25\right.$ $\left.\pm 0,02 \mathrm{~g} ; 35^{\circ} \mathrm{C}: 3,12 \pm 0,01 \mathrm{~g}\right)$. However, at a certain level, bacteria grow slowly although temperature still increases. It is because the activation of enzyme system changes by heat. $\left(40^{\circ} \mathrm{C}-45^{\circ} \mathrm{C}\right.$ : no cellulosemembrane formation) [6]. Each spieces of micoroorganism has its own temperature limit for its growth. $25-35^{\circ} \mathrm{C}$ is the best temperature for the growth and cellulose synthesis of bacteria G. xylinus $\mathrm{T}_{9}$. Bacterial cellulose membrane is best produced at the temperature of $32^{\circ} \mathrm{C}$. Temperatures of over $35^{\circ} \mathrm{C}$ can inhibit the cellulose synthesis.
In general, the most appropriate temperature for the Bacterial cellulose membrane formation from bacteria $G$. xylinus $\mathrm{T}_{9}$ is $32^{\circ} \mathrm{C}$.

\subsection{Influence of surface area and fermenta- tion volume $(\mathrm{S} / \mathrm{V})$ on the formation of Bacte- rial cellulose membrane}

Having examined the formation of Bacterial cellulose membrane of bacteria $G$. xylinus $T_{9}$ with different ratios $\mathrm{S} / \mathrm{V}$, results are shown in Table 5 .

Bacteria G. xylinus are obigateearobes, so oxygen is the essential element for their growth. Accordingly, the ratio S/V has a great influence on the formation of Bacterial cellulose membrane. Data in Table 5 show that Bacterial cellulose membrane is best formed when the ratio $\mathrm{S} / \mathrm{V}$ is 0.8 and the depth of solution is $1.20 \mathrm{~cm}$.

Table 5. Influence of surface area and fermentation volume on the BC membrane formation from bacterium G. xylinus $\mathbf{T}_{9}$

\begin{tabular}{ccccc}
$\begin{array}{c}\text { Ratio S/V } \\
\left(\mathrm{cm}^{-1}\right)\end{array}$ & $\mathrm{h}(\mathrm{cm})$ & Properties of Bacterial cellulose membrane & $\mathrm{M} \pm \mathrm{m}$ & $\delta(\%)$ \\
\hline 0.5 & 2.20 & Very thin, amorphous & $0.65 \pm 0.02$ & 0.03 \\
0.6 & 1.70 & $1.05 \pm 0.02$ & 0.03 \\
\hline
\end{tabular}




\begin{tabular}{ccccc}
$\begin{array}{c}\text { Ratio S/V } \\
\left(\mathrm{cm}^{-1}\right)\end{array}$ & $\mathrm{h}(\mathrm{cm})$ & Properties of Bacterial cellulose membrane & $\mathrm{M} \pm \mathrm{m}$ & $\delta(\%)$ \\
\hline 0.7 & 1.45 & Poorly amorphous & $2.00 \pm 0.01$ & 0.02 \\
\hline $\mathbf{0 . 8}$ & $\mathbf{1 . 2 0}$ & & $\mathbf{3 . 3 3} \pm \mathbf{0 . 0 2}$ & $\mathbf{0 . 0 3}$ \\
0.9 & 1.10 & Smooth, tough, $1.5-3 \mathrm{~mm}$ thick & $3.17 \pm 0.01$ & 0.02 \\
1.0 & 1.00 & & $3.05 \pm 0.01$ & 0.02 \\
\hline 1.5 & 0.60 & Very thin, torn & $1.12 \pm 0.01$ & 0.02
\end{tabular}

M: average mass of membrane

$m$ : Mean error

$\delta$ : average squared deviation

S: surface area of culture $\left(\mathrm{cm}^{2}\right)$

$V$ : fermentation volume $\left(\mathrm{cm}^{3}\right)$

$h$ : Depth of fermentation solution $(\mathrm{cm})$

\section{Conclusion}

In the study, 6 strains of Gluconacetobacter xylinus bacteria were isolated, but we found that $T_{6}$ và $T_{9}$ have the best formation of Bacterial cellulose membrane, which matches the criteria of the nourishing face masks production. The ideal nutrional medium for the formation of Bacterial cellulose membrane in Spirulina from G. xylinus $\mathrm{T}_{9}$ is composed of: (NH4)2SO4: $0.5(\mathrm{~g}), \mathrm{KH}_{2} \mathrm{PO}_{4}: 1(\mathrm{~g})$, glucose: 10 $(\mathrm{g})$, alega powder: $20(\mathrm{~g})$, distilled water: $1000(\mathrm{ml})$. The time of bacteria culture is 5 days, appopriate $\mathrm{pH}$ is 5 , appropriate temperature is $32^{\circ} \mathrm{C}$, and the ratio between surface area and solution volume $(\mathrm{S} / \mathrm{V})$ is 0.8 .

\section{References}

[1] Alina Krystynowicz, Maria Koziolkiewicz, Agnieszka WiktorowskaJezierska, Stanislaw Bielecki, Emilia Klemenska, Alexander Masny, Andrzej Plucienniczak, (2005), "Molecular basis of cellulose biosynthesis disappearance in submerged culture of Acetobacter xylinum", Acta Biochim Pol, 52(3): 691698.

[2] Ben-Hayyim. G, Ohad. I, Ph.D., (1965), "Synthesis of cellulose by Acetobacterxylinum: VIII. On the formation and oriention of bacterial cellulose fibril in the presence of acidic polysaccharides", The Journal of Cell Biology, 25(2): 191-207.

[3] Frateur J. (1950), "Essai sur la systématique des Acetobacter", La cellule, 53: 278 - 398.

[4] Janssen P. H., Yates P. S., Grinton B. E., Taylor P. M., Sait M., (2002), "Improved culturability of soil bacteria and isolation in pure culture of novel members of the divisions Acidobacteria, Actinobacteria, Proteobacteria and Verrucomicrobia”, Appl. Environ. Microbiol., 68: 2391-2396.

[5] Nathan, P. \& Paul, (2011), “G. Bacterial cellulosebased materials and medical devices: current state and perspectives", Appl. Microbiol.Biot. 91: 12771286

[6] Schramm M., Hestrin S. (1954), "Factor affecting production of cellulose at the air/liquid interface of a culture of Acetobacter xylinum", J. gen. Microbiol, 11: 123-129.

[7] Zeng X., Small DP, Wan W, (2011), "Statistical optimization of culture conditions for bacterial cellulose production by Acetobacter xylinum BPR 2001 from maple syrup", Carbohydr. Polym, 85: 506-513. 